\title{
First report of Eocene gadiform fishes from the Trans-Urals (Sverdlovsk and Tyumen regions, Russia)
}

\author{
Giuseppe Marramà, ${ }^{1}$ Giorgio Carnevale, ${ }^{2}$ Pavel V. Smirnov, ${ }^{3,4}$ Yaroslav S. Trubin, ${ }^{3}$ and Jürgen Kriwet ${ }^{1}$ \\ ${ }^{1}$ University of Vienna, Department of Paleontology, Althanstrasse 14, 1090, Vienna, Austria < giuseppe.marrama@ univie.ac.at>, <juergen. \\ kriwet@univie.ac.at> \\ ${ }^{2}$ Università degli Studi di Torino, Dipartimento di Scienze della Terra, Via Valperga Caluso 35, 10125 Torino, Italy < giorgio.carnevale@ \\ unito.it> \\ ${ }^{3}$ Tyumen Industrial University, St. Volodarsky 38, 625000 Tyumen, Russia <geolog.08@ mail.ru>, <tmn.smirnov@ gmail.com> \\ ${ }^{4}$ Clausthal University of Technology, 38 Adolph-Roemer-Strasse 2A, 38678 Clausthal-Zellerfeld, Germany <geolog.08@mail.ru>
}

\begin{abstract}
The recent 2014-2017 controlled excavations carried out in quarries of Sverdlovsk and Tyumen regions, Ural and Western Siberia, are contributing to the knowledge of the middle to late Eocene marine fauna from the Turgay Strait, mainly composed of invertebrates and cartilaginous and bony fishes. Here we present a preliminary report of the bony fishes collected during the campaigns carried out in two Eocene Trans-Urals localities. The sediments of these localities were deposited in a large epicontinental marine basin during the middle to late Eocene, when the Turgay Strait connected the Arctic waters to the North and the Peritethys to the South. Most of the bony fish material examined can be assigned to codfishes (Gadiformes) according to morphological comparison with living and fossil taxa. In particular, nearly complete three-dimensionally preserved lower jaws are confidently assigned to the Merlucciidae, whereas isolated vertebrae and bones are referred to as Gadiformes incertae sedis. This report documents the easternmost occurrence of this group of fishes in the northern hemisphere during the early phases of their radiation, revealing their presence into the Turgay Strait before its closure.
\end{abstract}

\section{Introduction}

Fishes of the order Gadiformes (cods, hakes, and allies) include more than 600 living species arranged in 84 genera and 13 families, many of which are of high commercial importance, constituting over one quarter of the world's marine fish catch (Cohen et al., 1990; Nelson et al., 2016). Although morphological and molecular studies support the monophyly of the Gadiformes (e.g., Endo, 2002; Roa-Varón and Ortí, 2009), the within-group relationships remain problematic to establish (e.g., Grand et al., 2014; Hughes et al., 2018). Codfishes are widespread in all the oceans from polar to tropical waters, ranging from deep-sea, neritic, estuarine, and freshwater habitats (Cohen et al., 1990; Nelson et al., 2016). They are characterized by a set of morphological features (which are not unique to gadiforms), including a scapular foramen present between the scapula and coracoid, absence of basihyal, premaxilla forming the entire margin of upper jaw, toothless ectopterygoid, absence of orbitosphenoid and basisphenoid, hyomandibula with a single condyle, and lack of swim bladder or pneumatic duct (Endo, 2002; Nelson et al., 2016). Moreover, codfishes are unique in having a pince-nez-shaped saccular otolith often with a collicular crest above the ostium-cauda junction of the crista inferior (Endo, 2002; Borden et al., 2013; Grande et al., 2013).

Although a Cretaceous origin has been hypothesized from their sister-group relationships with zeiforms, reliable occurrences of fossil gadiforms are known only from Cenozoic deposits and include otoliths, isolated bones, and articulated skeletons (see
Cohen, 1984; Nolf and Steurbaut, 1989; Carnevale, 2007; Kriwet and Hecht, 2008; Carnevale et al., 2012; Carnevale and Harzhauser, 2013; Přikryl et al., 2016; Schwarzhans et al., 2017; Přikryl, 2018). The Cretaceous origin of this group seems to be also supported by the presence of a precocious bipolar distribution of their occurrences in the early Paleogene, with gadoids in the Paleocene of North Atlantic and North Sea Basin and macrouroids in the Southern Ocean (Kriwet and Hecht, 2008). In the Eocene, gadoids and macrouroids are represented in North America and several sites of Europe, including both Boreal and Tethyan localities, mostly by otoliths and isolated bones (see Kriwet and Hecht, 2008). The aim of this paper is to report a new occurrence of this group of fishes from middle to late Eocene sediments of the Sverdlovsk and Tyumen regions, Russia. Comparisons with other Eocene gadiforms from almost coeval deposits are provided, and paleobiogeographic implications are subsequently discussed.

\section{Geological setting}

The material examined comes from two localities of the TransUralian region and Western Siberia, Russia (Fig. 1). The Eocene sediments of these localities are part of the Tavda Formation, a widespread unit accumulated in the West Siberian basin during the Bartonian and Priabonian (middle to late Eocene) and established in 1944 by A. Bogdanovich in a pit near the Tavda town (Martynov et al., 1975; Shatskii, 1978). During the middle-late Eocene, the West Siberian Basin was a large epicontinental marine basin in which the Turgay Strait probably connected the Arctic 

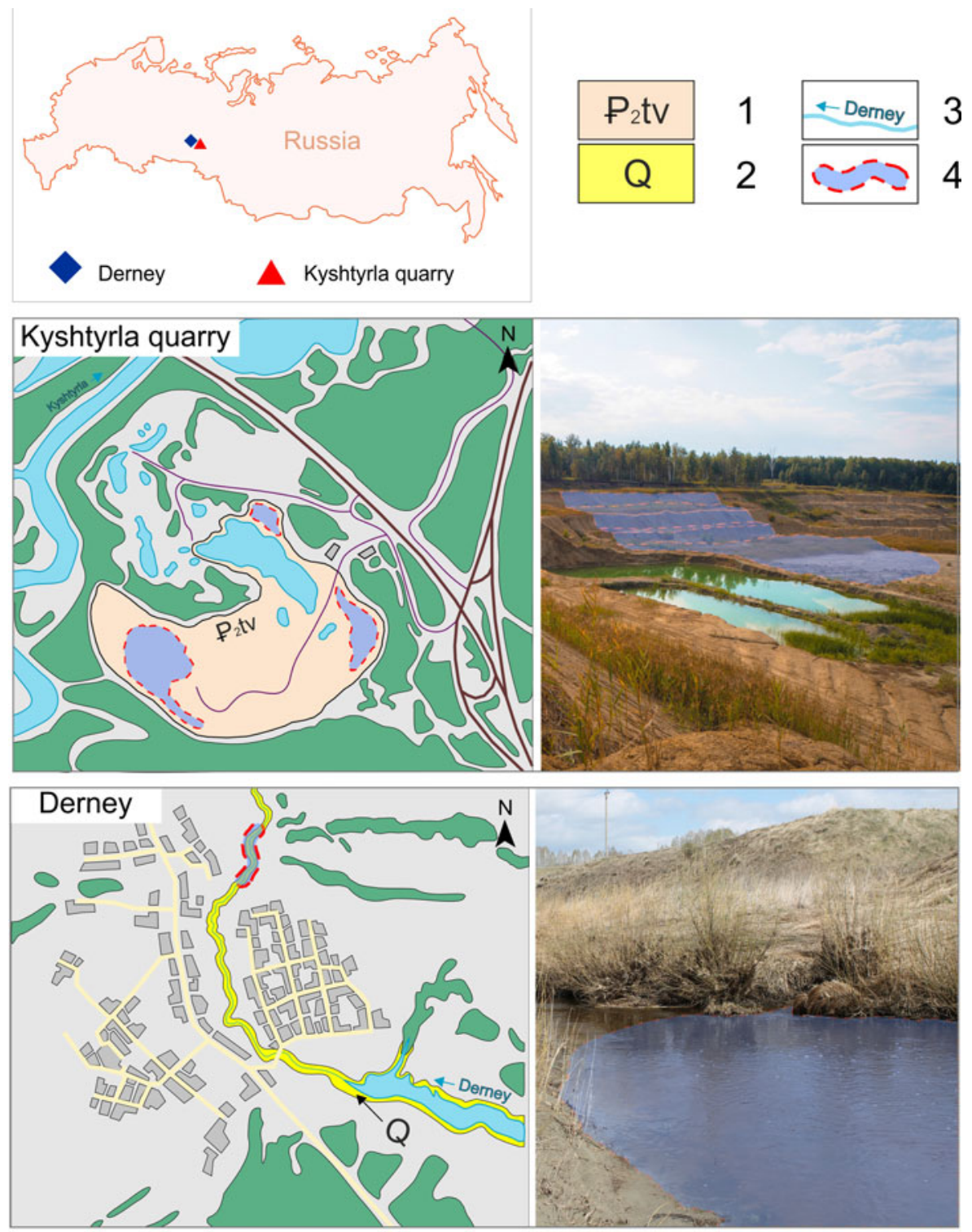

Figure 1. Location map and detailed overview of the provenance sites of the specimens. $1=$ Tavda Formation outcrops in Kyshtyrla quarry; $2=$ Quaternary sediments in Derney site; 3 = small rivers; 4 = sampling sites.

waters to the North and the Peritethys to the South, until the Eocene-Oligocene boundary (Yasamanov, 1976; Leonov, 1998). The Tavda Formation either overlies or slightly contacts the Irbit Formation. The deposits of the Kurtamysh and Atlym formations or continental Quaternary sediments directly overlie the Tavda Formation. The sediments consist of greenish-grey, bluish, black, and flake-like lenticular-layered montmorillonite and beidellite-mica clays, sometimes with silty and sandy clay intercalations including clayey diatomite, mica, silica, quartz, quartz-feldspar, quartz glauconite-grained sands, and siltstones. Most often, all of these mineral inclusions are confined to the base of the section and form a layer up to $15 \mathrm{~m}$ thick. Nodules and inclusions of siderites, marls, stress marks, phosphorite nodules, and gypsum crystals are also present. The thickness of the formation ranges from 10 to $15 \mathrm{~m}$ in the west to up to $220 \mathrm{~m}$ in the east.

The Tavda Formation is usually divided into lower and upper subformations. The lower subformation (20-100 m) is represented by greenish silty clay with thin interlayers $(1-2 \mathrm{~mm})$ of light grey sand and siltstone and is characterized by the Rhombodinium draco assemblage. According to recent studies on organic-walled microphytoplankton, planktonic and benthic foraminifera, the lower Tavda subformation is dated to the Bartonian (Akhmet'ev et al., 2004; Vasilyeva et al., 2006; Vasilyeva, 2015). The upper Tavda subformation (30-50 m), composed of greenish aleurite thin-layer clay with layers of clayey siderite, belongs to the Charlesdowinea clathrata angulosa assemblage, dating back to the Priabonian (Iakovleva et al., 2000; Akhmet'ev et al., 2004; Akhmet'ev and Beniamovski, 2006). These data are included in the current stratigraphic scheme of the region (Unified regional stratigraphic schemes for Neogene and Paleogene deposits of the West Siberian Plain, 2001).

Kyshtyrla.-Part of the material comes from Kyshtyrla, a clay pit located $4 \mathrm{~km}$ southeast of the village of Vinzili, $2 \mathrm{~km}$ northeast of the village of Kyshtyrla, $5 \mathrm{~km}$ northwest of the 
Bogandinskaya railway station, and $33 \mathrm{~km}$ south of the city of Tyumen (Tyumen region, Russia) (Fig. 1). From a geomorphologic point of view, the area is a hilly plain with altitude of 55-65 m confined to the first and (partially to) the second terraces of Pyshma river. The clays are exposed for about $14 \mathrm{~m}$, whereas during exploratory drillings the maximum measured thickness was at least $60-80 \mathrm{~m}$. The clays are covered by Quaternary clay and sandy sediments through a nondepositional unconformity. Clays in the lower part of the section form a single horizon with a thickness of up to $5 \mathrm{~m}$ of dark-grey, aleuritic, layered sediments. The upper part of the section is represented by a $9 \mathrm{~m}$ thick horizon of bluish-grey and greenish-grey aleuritic clays including small scales of mica. The associated fossils include mollusk shells, isolated shark teeth, fragments of bony fishes, and carbonaceous plant remains (Trubin, 2018; Popov et al., 2019). Abundant bioturbation traces are also present (Nesterov et al., 2018).

Derney.-The other locality is represented by a series of small cliffs near the Derney river in the Borovlyanskoe village (Sverdlovsk region), which is located $170 \mathrm{~km}$ from Yekaterinburg. The fossils from this locality are reworked from the Eocene Tavda Formation into Pleistocene blue silty clays of fluvial origin (Stefanovsky et al., 2002; Malyshkina, 2003, 2006, 2012). The lower part of the section is a vivianite-rich blue clay with the fossil remains of large late Pleistocene mammals, including Mammuthus primigenius (Blumenbach, 1799), Coelodonta antiquitatis (Blumenbach, 1807), Rangifer sp., and Equus sp. (Malyshkina, 2006). The upper part of the section consists of grey quartz sands, with lenses of silty clay and coarser material, in which Eocene shark teeth and isolated bony fish remains are associated with Pleistocene tetrapods (Stefanovsky et al., 2002; Malyshkina, 2006). Due to their reworked nature, the fossils are mostly represented by poorly preserved isolated remains.

\section{Materials and methods}

The fossil material was obtained during fieldwork carried out by P. Smirnov and Y. Trubin in the Kyshtyrla and Derney sites from 2014 to 2017. The specimens were collected from the surface and during the screen washing of sediments with a sieve of $1 \mathrm{~mm}$ mesh size. The preparation of the fossils was carried out in an alkaline solution to remove the clay material following the method of Guzhov (2009). Part of the matrix associated with fossils was mechanically removed using needles and small scalpels. The material was examined using a Leica Wild M3C stereomicroscope equipped with a camera lucida drawing arm. The specimen Kr-BF-24 was investigated noninvasively with a micro-CT device SkyScan/Bruker 1173 at the Department of Paleontology of University of Vienna, and the processing of the TIFF-image stacks was performed with Amira v.5.4.1 (Visualization Sciences Group). Measurements were taken to the nearest $0.1 \mathrm{~mm}$ using the software TpsDig 2.19 (Rohlf, 2005). Osteological terminology mostly follows Inada (1981) and Endo (2002).

Repositories and institutional abbreviations.-Fossils are kept in the Museum of the History of Science and Technology of
Zauralie, Tyumen Industrial University, Russia. Specimens are labelled with $\mathrm{Kr}-\mathrm{BF}$ ( $\mathrm{Kr}$ stands for 'collectible miscellaneous,' 'Коллекционное разное' in Russian, and BF stands for 'bony fishes'). Extant specimens used for comparisons are housed in the Evolutionary Morphology Research Group lab at the Department of Palaeontology, University of Vienna (EMRG) and Naturhistorisches Museum Wien (NMW).

\section{Systematic paleontology}

\author{
Subdivision Teleostei sensu Patterson and Rosen, 1977 \\ Order Gadiformes Goodrich, 1909 \\ Family Merlucciidae Gill, 1884 \\ Genus indeterminate, species indeterminate
}

Figures 2, 3.3, 4

Description.-The specimen Kr-BF-24 consists of a single nodule that contains two contralateral partially articulated dentaries pertaining to a single individual (Fig. 2). The specimen is three-dimensionally preserved. The overall morphology of the lower jaws is consistent with that characteristic of the Merlucciidae (see Inada, 1981). The dentary is large, trapezoid in shape, measuring about $93 \mathrm{~mm}$ in length and $46 \mathrm{~mm}$ in height, although its posteriormost portion seems to be absent. The dentary is narrow at the symphysis, becoming gradually higher posteriorly. When observed in occlusal or ventral view the dentaries appear moderately arched, with concave inner and convex outer margins. The ventral median keel, which is typical in several gadiforms such as Merluccius and Gadus (Fig. 3.1; see also Claeson et al., 2012), is deep, slightly higher than the dorsal part of the dentary and separated from the latter by a deep sensory groove. The pores of the mandibular sensory canal are difficult to recognize. There are two rows of large, fang-like, and regularly spaced teeth on the alveolar surface of each dentary, resembling the condition of some living gadiforms (Fig. 3.1, 3.2). The teeth are sharp, slim, and smooth, having roughly the same size throughout the jaws. Small caps of acrodin can be recognized in some teeth (Fig. 4.1), resembling the condition of some modern (e.g., Merluccius; see Fig. 3.2) and extinct merlucciids (e.g., Rhinocephalus; Rosen and Patterson, 1969). Large pulp cavities can also be recognized through the micro-CT scan (Fig. 3.3). The teeth of the outer and inner rows are mesially and posteriorly curved. Being morphologically similar, a single isolated tooth (Kr-BF-11; Fig. 4.2) seems to pertain to the same group, whereas another isolated tooth (Kr-BF-9; Fig. 4.3), which is more robust and shallower, is only tentatively referred to Merlucciidae herein.

Materials.-Kr-BF-24, a single nodule containing threedimensionally preserved lower jaws, Kyshtyrla site; Kr-BF-9, isolated tooth, Derney site; Kr-BF-11, isolated tooth, Derney site.

Remarks.-The almost complete lower jaws described herein can be aligned to the gadiform family Merlucciidae due to the presence of some characters, including a deep keel on the dentary and sharp and pointed fang-like teeth arranged in two 
1

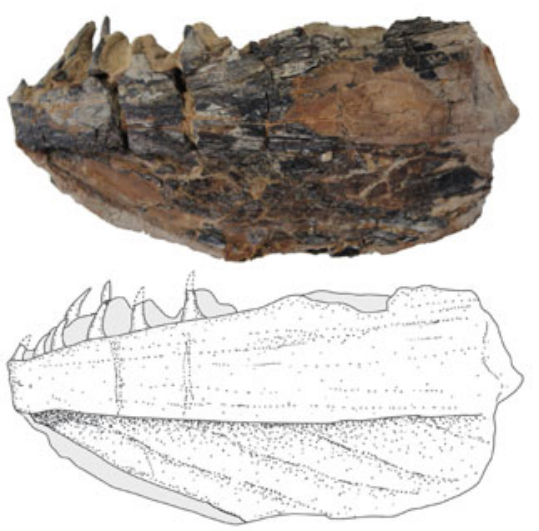

2

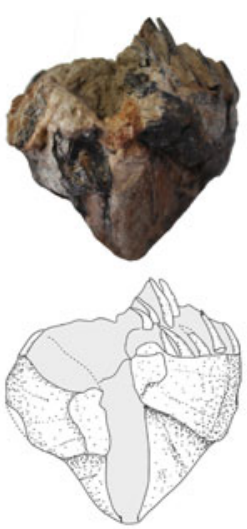

3

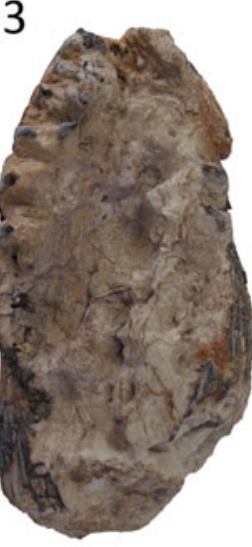

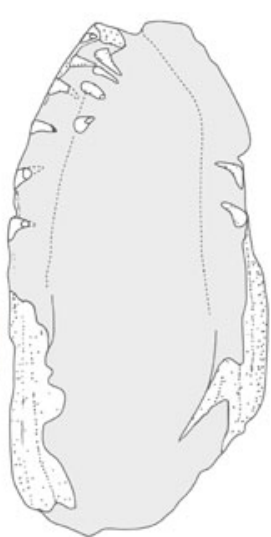
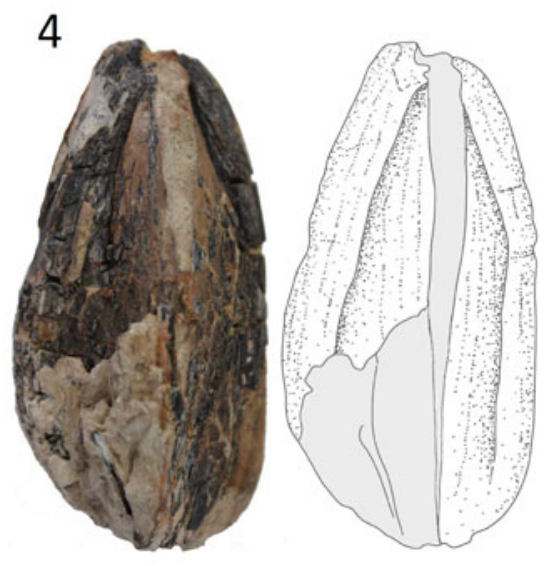

Figure 2. Specimen Kr-BF-24 with interpretative drawings. (1-4) Lower jaws (dentaries) of Merlucciidae incertae sedis in (1) lateral, (2) anterior, (3) occlusal, and (4) ventral views. Scale bar $=20 \mathrm{~mm}$.

rows and with small caps of acrodin (see Rosen and Patterson, 1969; Inada, 1981; Bieńkowska-Wasiluk et al., 2013, fig. 13). Eocene lower jaws of gadiform fishes were reported from the La Meseta Formation in Antarctica by Jerzmańska and Świdnicki (1992) and identified as Merlucciidae by Claeson et al. (2012), although Bieńkowska-Wasiluk et al. (2013) assigned this material to the cod icefishes of the percomorph suborder Notothenioidei. The overall appearance of the dentaries from the middle-late Eocene of Tyumen region is quite different from the jaws from the Eocene of Antarctica and from those of other Eocene fossil gadiforms such as Rhinocephalus (Rosen and Patterson, 1969), being much shallower and more elongated.

\section{Order Gadiformes Goodrich, 1909 \\ Family indeterminate}

Figure 5

Description.-The material reported herein is tentatively referred to the Gadiformes due to the considerable similarities with the extant taxa (e.g., Brosme, Gadus, Macrouronus, Merluccius, Molva, Pollachius) as well as with fossil material from other Eocene localities (e.g., Inada, 1981; Cohen, 1989; Howes, 1991a; Endo, 2002).
The overall morphology of the vertebrae is very similar to that of the gadiform centra from the Eocene of La Meseta Formation, Antarctica, described and figured by Jerzmańska (1988) and Jerzmańska and Świdnicki (1992) (compare also Tercerie et al., 2016). The vertebrae are massive and well ossified, strongly amphicoelous, subrectangular in outline, and higher than long (Fig. 5.1, 5.2). Distinct growth rings can be recognized on both anterior and posterior faces. Only the base of neural arches is preserved, suggesting that they were fused to centra. The vertebrae $\mathrm{Kr}-\mathrm{BF}-5, \mathrm{Kr}-\mathrm{BF}-6$, and $\mathrm{Kr}-\mathrm{BF}-7$ pertain to the abdominal portion of the body since they are trapezoid in cross section with their minimum and maximum width at their dorsal and ventral margins, respectively. Part of a large parapophysis is preserved on the ventral surface of the vertebra Kr-BF-6 (Fig. 5.1), suggesting that it might have been part of the posterior portion of the abdominal region. Unfortunately, due to inadequate preservation, it is not possible to detect the length of the base of the parapophysis. Along the dorsal surface, two narrow but deep grooves are separated by a thin bony lamella (Fig. 5.1, 5.2), whereas two or three grooves can be recognized on the lateral sides. A single narrow groove is present on the ventral surface of all the vertebrae, and broad and deep depressions can be observed medially to the base of the right and left parapophyses (Fig. 5.1). Prezygapophyses are mostly not preserved, but small and fan-shaped postzygapophyses are visible in Kr-BF-4 (Fig. 5.2; arrow). The large 

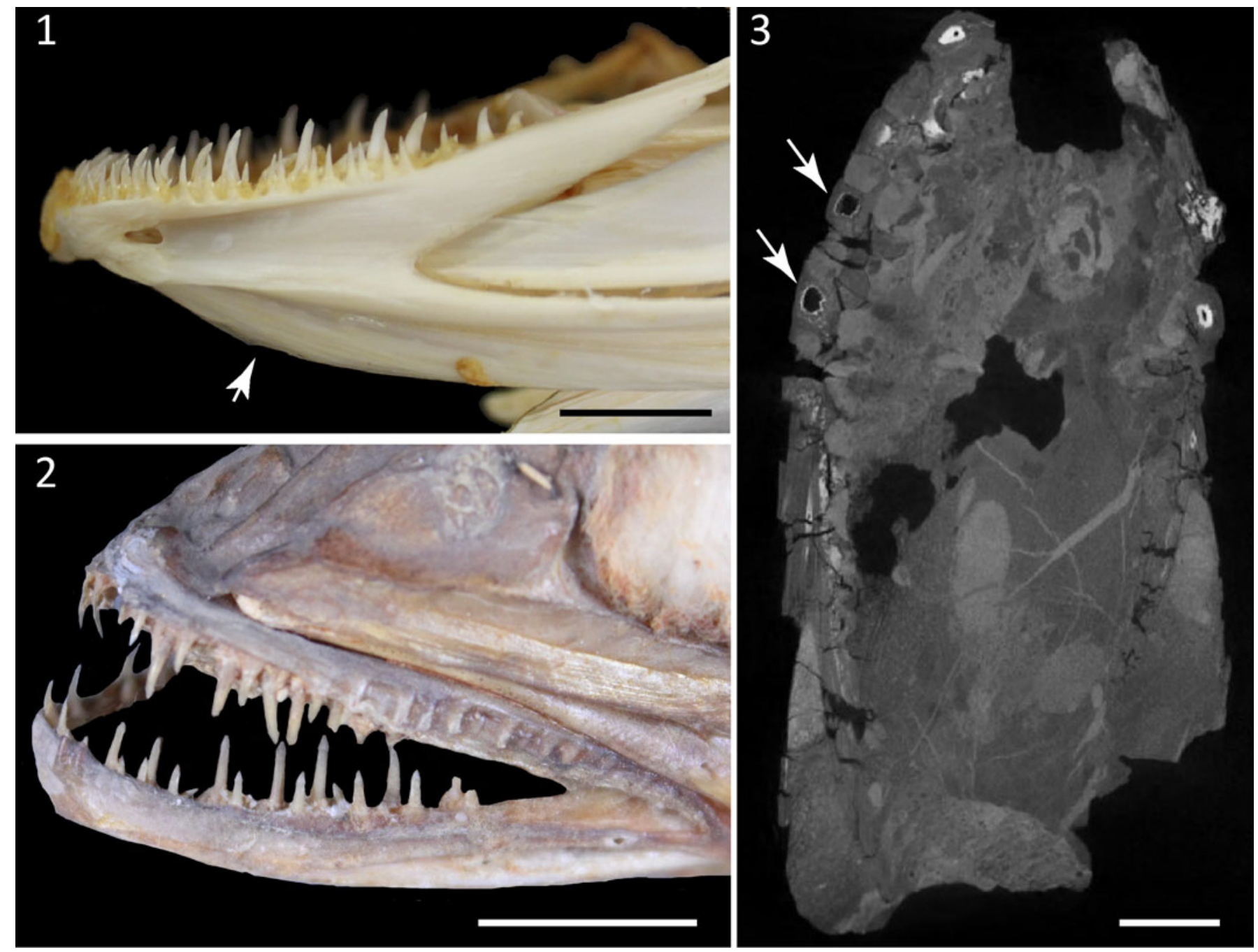

Figure 3. Comparative extant material and detail of the micro-CT scan. (1) Detail of the dentary of Gadus morhua (EMRG-Act-H-1) showing a deep ventral keel (arrow); (2) close-up of the jaws of Merluccius vulgaris (NMW 79449); (3) Kr-BF-24, image taken from micro-CT scan showing the large pulp cavities of some teeth (arrows). Scale bars $=10 \mathrm{~mm}$.
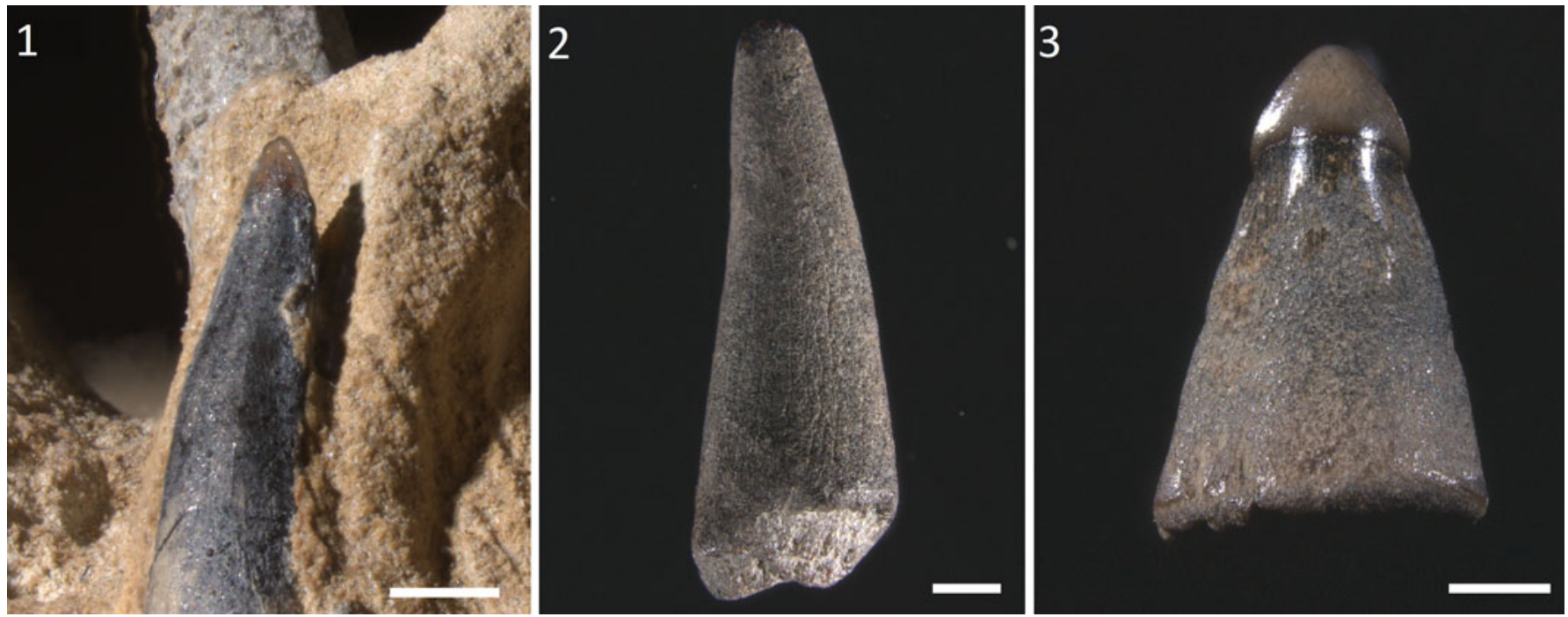

Figure 4. Fossil remains referred to Merlucciidae incertae sedis. (1) Close-up of a tooth of specimen Kr-BF-24 showing the small cap of acrodin; (2) Kr-BF-11, isolated tooth; (3) Kr-BF-9, isolated tooth tentatively referred to Merlucciidae. Scale bars $=1 \mathrm{~mm}$. 

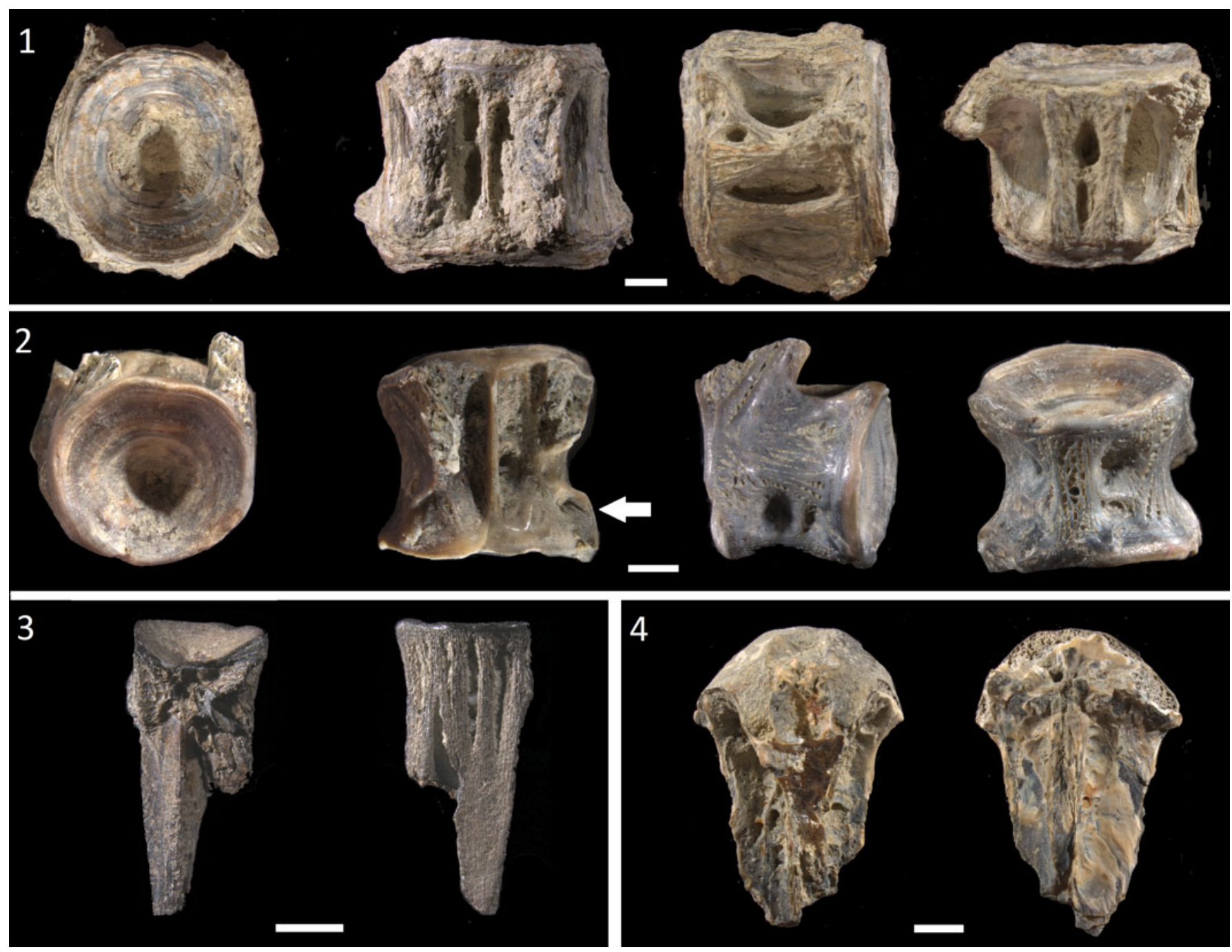

Figure 5. Fossils referred to Gadiformes incertae sedis. (1) Kr-BF-6, isolated vertebral centrum in (from left to right) anterior, dorsal, lateral, and ventral views; (2) $\mathrm{Kr}-\mathrm{BF}-4$, isolated vertebral centrum in (from left to right) anterior, dorsal, lateral, and ventral views; (3) Kr-BF-14, basioccipital in dorsal (left) and ventral views (right); (4) Kr-BF-3, vomer in dorsal (left) and ventral views (right). Scale bars $=2 \mathrm{~mm}$.

size of the vertebrae (about $10 \mathrm{~mm}$ in diameter) might indicate that they were from large individuals.

The material also includes an isolated basioccipital (Kr-BF-14; Fig. 5.3), which is elongate and measures about $9 \mathrm{~mm}$ in length and $4 \mathrm{~mm}$ in width. In dorsal view, it is possible to recognize an irregular face for the articulation with the exoccipitals. In posterior view, the facet for the articulation with the first centrum is ovoid in shape. In ventral view, there is no trace of the sutural surface for the parasphenoid, suggesting that the bone is incomplete and some millimeters are missing from its anterior edge.

The specimen Kr-BF-3 seems to represent a part of a vomer (Fig. 5.4). It measures about $13 \mathrm{~mm}$ in length, but it is likely that most of the posterior part of the bone is missing. The head of the vomer is robust and considerably widened, whereas its ventral margin is apparently toothless, resembling the condition of Muraenolepis and some morids (e.g., Danilchenko, 1967; Endo, 2002), although we cannot exclude that this might be a taphonomic artefact. The lateral wings of the vomer are represented by tiny sheets of bones separating the dorsal from the ventral sides.
Materials.-Kr-BF-4, Kr-BF-5, Kr-BF-6, and $\mathrm{Kr}-\mathrm{BF}-7$ : isolated vertebral centra, Kyshtyrla site; Kr-BF-15, and Kr-BF-17: isolated vertebral centra, Derney site; Kr-BF-14: a single basioccipital, Derney site; Kr-BF-3: partial vomer, Kyshtyrla site.

Remarks.-Isolated vertebral centra belonging to indeterminate gadiforms were also reported from the Eocene of the La Meseta Formation in Antarctica by Jerzmańska (1988) and Jerzmańska and Swidnicki (1992). Nevertheless, the attribution of the Antarctic vertebrae to this group of bony fishes has been questioned by Bieńkowska-Wasiluk et al. (2013), who pointed out that strong parapophyses and the presence of several lateral bony lamellae are shared by gadiforms and some nothenioids. However, our comparison of the Eocene vertebrae from Russia and those figured by Tercerie et al. (2016) shows that several gadiforms (including Gadus, Macruronus, and Merluccius) do exhibit abdominal and caudal vertebral centra higher than long, therefore supporting our attribution of the vertebrae from the Eocene of Russia to the Gadiformes. 

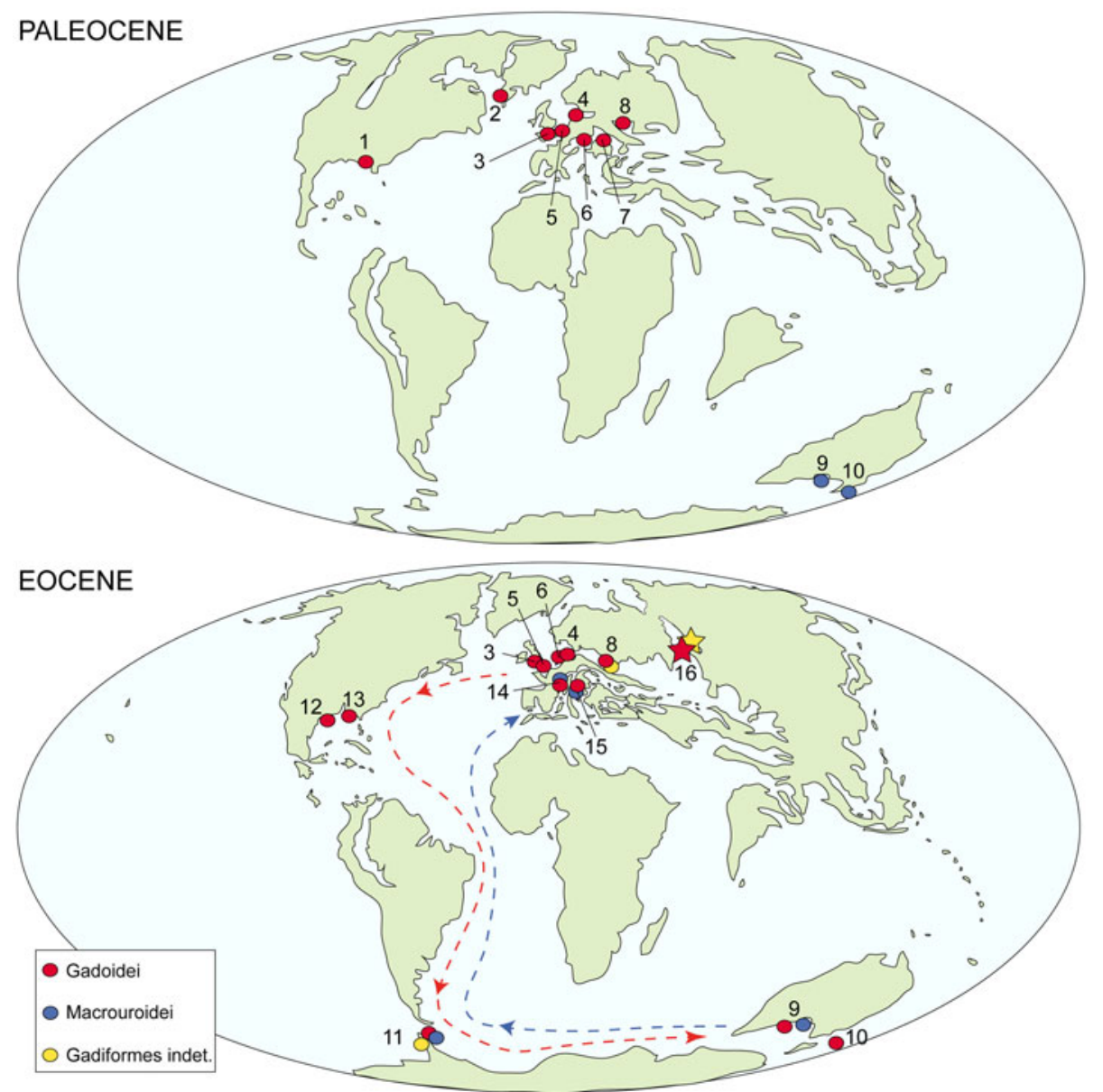

Figure 6. Paleobiogeographic distribution of gadiform occurrences in the Paleocene and Eocene according to Schwarzhans (1985, 2012), Nolf and Dockery (1993), Kriwet and Hecht (2008), and Schwarzhans and Bratishko (2011). The arrows indicate the possible migration routes of gadoids (red) and macrouroids (blue) that occurred in the Eocene. The stars represent the occurrences from Tyumen and Sverdlovsk regions reported in this study. Maps are modified from Scotese (2002). $1=$ Alabama; $2=$ Greenland; 3 = England; $4=$ Denmark; 5 = Belgium; $6=$ Germany; $7=$ Austria; $8=$ Ukraine; $9=$ Australia; $10=$ New Zealand; $11=$ Antarctica; $12=$ Texas; $13=$ Louisiana; $14=$ France; $15=$ Italy; $16=$ Russia .

\section{Origin and early paleogeographic distribution}

The oldest reliable gadiform remains are from Paleocene deposits and include about 20 occurrences from 10 localities (Fig. 6). More precisely, the oldest known gadiform appears to be a partially complete articulated gadoid skeleton from the Danian of West Greenland (Rosen and Patterson, 1969; Cohen, 1984). Early gadoids also are known from isolated otoliths recorded from the Paleocene-early Eocene of Austria, Belgium, Denmark, Germany, Greenland, United Kingdom, Ukraine, and United States (Schwarzhans, 2003, 2004, 2012; Schwarzhans and Bratishko, 2011). Macrouroid otoliths were reported from the Paleocene of southern Australia and New Zealand (e.g., Schwarzhans, 1985), possibly indicating a Southern Hemisphere origin for this group and a subsequent migration to the Northern Hemisphere through the northern margin of Antarctica and an Atlantic corridor (Kriwet and Hecht, 2008) (Fig. 6). This might suggest that two origination and radiation events of modern gadiform lineages occurred in the early history of gadiforms, with gadoids originating and evolving in the Northern Hemisphere, while macrouroids diversified in the Southern Hemisphere (Kriwet and Hecht, 2008). This already wide and distinct distribution in the Paleocene might indicate that the origin of gadiforms possibly occurred in the Late Cretaceous, although no reliable records from the Mesozoic have been reported so far (see Svetovidov, 1948; Fedotov and Bannikov, 1989; Kriwet and Hecht, 2008; Carnevale and Johnson, 2015). The gadoid migration into the Southern Hemisphere possibly occurred very early in their evolutionary history, likely in relation to oceanic adaptations (Kriwet and Hecht, 2008) and following the same corridor suggested for other Eocene marine fish lineages (Long, 1994; Marramà et al., 2018a, b). Howes (1991b) suggested that gadoids migrated from oceanic to shelf habitat during their early evolution. However, the fossil record seems to contradict this hypothesis since most of the early gadoids are from shelf areas of the North Sea Basin with a maximum depth of about $250 \mathrm{~m}$ during the Paleocene (Gemmer et al., 2002).

\section{Conclusions}

About 50 gadiform occurrences from more than a dozen localities have been reported in the Eocene (Kriwet and Hecht, 2008). In this period, gadiforms were already widespread and 
well diversified in both the Northern and Southern Hemispheres, and their skeletal remains and otoliths have been reported from Europe, North America, Oceania, and Antarctica up to now (e.g., Schwarzhans, 1980, 1981; Bonde et al., 2008, 2011; Kriwet and Hecht, 2008). The present report of merlucciid and indeterminable gadiform remains from the middle-late Eocene of the Trans-Urals Russia extends the paleogeographic distribution of this group of fishes in the Northern Hemisphere eastward during their early radiation, providing evidence of the existence of a gadoid contingent in the Turgay Strait just before its definitive closure.

\section{Acknowledgments}

The authors thank V. Alifanov (Paleontological Institute, Russian Academy of Sciences) for the useful suggestions and assistance to preparation and B. Riedel (Naturhistorisches Museum Wien) for the access to comparative material under her care. Thanks are also due to C. Pfaff (University of Vienna) for performing micro-CT scans of the specimen Kr-BF-24 and to J. Cawley (University of Vienna) for improving the English of our manuscript. The manuscript has been greatly improved by the valuable revisions of $T$. Prikryl (Czech Academy of Sciences), by an anonymous reviewer, and by editorial comments of A. Murray and H.-D. Sues. Financial support was provided by the Austrian Science Fund (FWF) [M2368-B25 to G.M.] and Università degli Studi di Torino [ex-60\% 2017 and 2018 grants to G.C.]. Open access funding provided by Austrian Science Fund (FWF).

\section{References}

Akhmet'ev, M.A., and Beniamovski, V.N., 2006, The Paleocene and Eocene in the Russian part of West Eurasia: Stratigraphy and Geological Correlation, v. 14 , p. $49-72$

Akhmet'ev, M.A., Aleksandrova, G.N., Beniamovskii, V.N., Vitukhin, D.I., Glezer, Z.I., et al., 2004, New data on the marine Paleogene of the southern West Siberian Plate, Paper 2: Stratigrafiya Geologicheskaya Korrelyatsiya, v. 12 , p. $65-86$

Bieńkowska-Wasiluk, M., Bonde, N., Møller, P.R., and Gaździcki, A., 2013, Eocene relatives of cod icefishes (Perciformes: Notothenioidei) from Seymour Island, Antarctica: Geological Quarterly, v. 57, p. 567-582.

Blumenbach, J.F., 1799, Handbuch der Naturgeschichte. Sechste auflage: Göttingen, Dieterich, $697 \mathrm{p}$.

Blumenbach, J.F., 1807, Handbuch der Naturgeschichte. Achte auflage: Göttingen, Dieterich, $743 \mathrm{p}$.

Bonde, N., Andersen, S., Hald, N., and Jakobsen, S.L., 2008, Danekrä-Denmark's Best Fossils: Copenhagen, Gyldendal, 224 p.

Bonde, N., Madsen, H., Schultz, B., Sylvestersen, R., and Jakobsen, S.L., 2011, Mo-clay in North Jutland-diatomite and fossils: Dansk Naturhistorisk Forening, v. 19-20, p. 25-40 [in Danish].

Borden, W.C., Grande, T.C., and Smith, W.L., 2013, Comparative osteology and myology of the caudal fin in the Paracanthopterygii (Teleostei: Acanthomorpha), in Arratia, G., Schultze, H.-P., and Wilson, M.V.H., eds., Mesozoic Fishes 5-Global Diversity and Evolution: Munich, Verlag Dr. Friedrich Pfeil, p. 419-455.

Carnevale, G., 2007, New gadiform fishes (Teleostei, Gadiformes) from the Miocene of Algeria: Journal of African Earth Sciences, v. 47, p. 95-111.

Carnevale, G., and Harzhauser, M., 2013, Middle Miocene rockling (Teleostei, Gadidae) from the Paratethys (St. Margarethen in Burgenland, Austria): Bulletin of Geosciences, v. 88, p. 609-620.

Carnevale, G., and Johnson, G.D., 2015, A Cretaceous cusk-eel (Teleostei, Ophidiiformes) from Italy and the Mesozoic diversification of percomorph fishes: Copeia, v. 103, p. 771-791.

Carnevale, G., Harzhauser, M., and Schultz, O., 2012, The Miocene gadid fish Palimphemus anceps Kner, 1862: A reappraisal: Geodiversitas, v. 34, p. 625-643.
Claeson, K.M., Eastman, J.T., and Macphee, R., 2012, Definitive specimens of Merlucciidae (Gadiformes) from the Eocene James Ross Basin of Isla Marambio (Seymour Island), Antarctic Peninsula: Antarctic Science, v. 24, p. $467-472$.

Cohen, D.M., 1984, Gadiformes: Overview, in Moser, H.G., Richards, W.J., Cohen, D.M., Fahay, M.P., Kendall, A.W., and Richardson, S.L., eds., Ontogeny and Systematics of Fishes: American Society of Ichthyologists and Herpetologists Special Publication no. 1, p. 259-265.

Cohen, D.M., 1989, Papers on the Systematics of Gadiformes: Natural History Museum, Los Angeles County, Science Series 32, 262 p.

Cohen, D.M., Inada, T., Iwamoto, T., and Scialabba, N., 1990, Gadiform Fishes of the World-An Annotated and Illustrated Catalogue of Cods, Hakes, Grenadiers and other Gadiform Fishes known to Date: Rome, FAO Fisheries Synopsis 10, $442 \mathrm{p}$.

Danilchenko, P.G., 1967, Bony Fishes of the Maikop Deposits of the Caucasus: Jerusalem, Israel Program for Scientific Translations, $247 \mathrm{p}$.

Endo, H., 2002, Phylogeny of the order Gadiformes (Teleostei, Paracanthopterygii): Memoirs of the Graduate School of Fisheries Sciences, Hokkaido University, v. 49, p. 75-149.

Fedotov, V.F., and Bannikov, A.F., 1989, On the phylogenetic relationships of fossil Gadidae, in Cohen, D.M., ed., Papers on the Systematics of Gadiform Fishes, Volume 32: Los Angeles, Natural History Museum of Los Angeles County, p. 187-196.

Gemmer, L., Huuse, M., Clauden, O.R., and Nielsen, S.B., 2002, Mid-Palaeocene palaeogeography of the eastern North Sea basin: Integrating geological evidence and 3D geodynamic modelling: Basin Research, v. 14, p. 329-346.

Gill, T., 1884, On the Anacanthini fishes: Proceedings of the Academy of Natural Sciences of Philadelphia, v. 36, p. 167-183.

Goodrich, E.S., 1909, Vertebrata Craniata. Fascicule I. Cyclostomes and fishes, in Lankaster, E.R. ed., A Treatise on Zoology, Part 9: London, Adam \& Charles Black, $518 \mathrm{p}$.

Grand, A., Zaragüeta Bagils, R., Vélez, L.M., and Ung, V., 2014, A cladistic re-analysis of the Gadiformes (Teleostei, Paracanthopterygii) using three-item analysis: Zootaxa, v. 3889, p. 525-552.

Grande, T.C., Borden, W.C., and Smith, W.L., 2013, Limits and relationships of Paracanthopterygii: A molecular framework for evaluating past morphological hypotheses, in Arratia, G., Schultze, H.-P., and Wilson, M.V.H., eds., Mesozoic Fishes 5-Global Diversity and Evolution: Munich, Verlag Dr. Friedrich Pfeil, p. 385-418.

Guzhov, A.V., 2009, Use of calcium bicarbonate for extracting fossils from clay rocks: Paleostrat-Annual meeting of the Paleontology section of the Moscow Society of Naturalists and the Department of the Paleontological Society of Moscow, Technical Program and Abstracts, p. 11-12 [in Russian].

Howes, G.J., 1991a, Anatomy, phylogeny and taxonomy of the gadoid fish genus Macruronus Günther, 1873, with a revised hypothesis of gadoid phylogeny: Bulletin of the British Museum of Natural History (Zoology), v. 51, p. $77-110$.

Howes, G.J., 1991b, Biogeography of gadoid fishes: Journal of Biogeography, v. 18 , p. $595-622$.

Hughes, L.C., et al., 2018, Comprehensive phylogeny of ray-finned fishes (Actinopterygii) based on transcriptomic and genomic data: Proceedings of the National Academy of Science USA, v. 115, p. 6249-6254.

Iakovleva, A.I., Rosseau, D.-D., and Cavagnetto, C., 2000, Paleocene-Eocene dinoflagellate cysts and continental palynomorphs from borehole N 4 (Vasugan Basin, Central Western Siberia): Palinology, v. 24, p. 187-200.

Inada, T., 1981, Studies on the merlucciid fishes: Bulletin Far Seas Fisheries Research Laboratory, v. 18, p. 1-172.

Jerzmańska, A., 1988, Isolated vertebrae of teleostean fishes from the Palaeogene of Antarctica: Polish Polar Research, v. 9, p. 421-435.

Jerzmańska, A., and Świdnicki, J., 1992, Gadiform remains from the La Meseta Formation (Eocene) of Seymour Island, West Antarctica: Polish Polar Research, v. 13, p. 241-253.

Kriwet, J., and Hecht, T., 2008, A review of early gadiform evolution and diversification: First record of rattail fish skull (Gadiformes, Macrouridae) from the Eocene of Antarctica, with otoliths preserved in situ: Naturwissenschaften, v. 95, p. 899-907.

Leonov, Y.G., 1998, Geologcheskie i Biotičeskie Sobya Pozdnego EocenaRannego Oligocena na Territorii Byshego SSSR. II: Geologcheskie i bioticheskie sobya: Trudy GIN 507, GEOS, Moskva, 249 p. [in Russian with English summary].

Long, D.J., 1994, Quarternary colonalization or Paleogene persistence? Historical biogeography of skates (Chondrichthyes: Rajidae) in the Antarctic Ichthyofauna: Paleobiology, v. 20, p. 215-228.

Malyshkina, T.P., 2003, Late Eocene Elasmobranchii in the Pleistocene fluvial taphocenosis in the middle Trans-Ural: Biostratigraphic and palaeogeographic importance: Litosfera, v. 4, p. 84-91 [in Russian with English summary].

Malyshkina, T.P., 2006, Late Eocene scyliorhinid sharks from the Trans-Urals, Russia: Acta Palaeontologica Polonica, v. 51, p. 465-475. 
Malyshkina, T.P., 2012, New sharks of the genus Abdounia (Carcharhiniformes: Carcharhinidae) from the Upper Eocene of the Trans-Ural Region: Paleontological Journal, v. 46, p. 392-399.

Marramà, G., Engelbrecht, A., Mörs, T., Reguero, M.A., and Kriwet, J., 2018a, The southernmost occurrence of Brachycarcharias (Lamniformes, Odontaspididae) from the Eocene of Antarctica provides new information about the paleobiogeography and paleobiology of Paleogene sand tiger sharks: Rivista Italiana di Paleontologia e Stratigrafia, v. 124, p. 283-298.

Marramà, G., Schultz, O., and Kriwet, J., 2018b, A new Miocene skate from the Central Paratethys (Upper Austria): The first unambiguous skeletal record for the Rajiformes (Chondrichthyes: Batomorphii): Journal of Systematic Palaeontology, doi:10.1080/14772019.2018.1486336.

Martynov, V.A., Sigov, A.P., and Chirva, S.A., 1975, The West Siberian Plate, in Grossgeim, V.A., and Korobkov, I.A., eds., Stratigrafiya SSSR. Paleogenovaya sistema [Stratigraphy of the Soviet Union: Paleogene System]: Moscow, Nedra, p. 315-329.

Nelson, J.S., Grande, T.C., and Wilson, M.V.H., 2016, Fishes of the World: Hoboken, John Wiley \& Sons, $752 \mathrm{p}$.

Nesterov, I.I., Trubin, Y.S., Smirnov, P.V., and Yan, P.A., 2018, First findings of trace fossils from the Tavda Formation (Middle-Upper Eocene) in the southwestern part of Western Siberia: Doklady Earth Sciences, v. 481, p. 862-865.

Nolf, D., and Dockery, D.T., 1993, Fish otoliths from the Matthews Landing Marl Member (Porters Creek Formation), Paleocene of Alabama: Mississippi Geology, v. 14, p. 24-39.

Nolf, D., and Steurbaut, E., 1989, Importance and restrictions of the otolithbased fossil record of gadiform and ophidiiform fishes, in Cohen, D.M., ed., Papers on the Systematics of Gadiform Fishes, Volume 32: Los Angeles, Natural History Museum of Los Angeles County, p. 47-58.

Patterson, C., and Rosen, D.E., 1977, Review of the ichthyodectiforms and other Mesozoic teleost fishes and the theory and practice of classifying fossils: Bulletin of the American Museum of Natural History, v. 158, p. 81-172.

Popov, S.V., Trubin, Y.S., Smirnov, P.V., Ordovsky, V.V., Goncharova, I.A., and Amitrov, O.V., 2019, On the taxonomic composition of mollusks from the Tavda Formation of Western Siberia: Paleontological Journal, v. 53 , p. $20-29$.

Přikryl, T., 2018, A morid cod (Gadiformes, Moridae) from the early Oligocene deposits of the Czech Republic: Comptes Rendus Palevol, v. 17, p. 536-544.

Přikryl, T., Brzobohatý, R., and Gregorová, R., 2016, Diversity and distribution of fossil codlets (Teleostei, Gadiformes, Bregmacerotidae): Review and commentary: Palaeobiodiversity and Palaeoenvironments, v. 96, p. 13-39.

Roa-Varón, A., and Ortí, G., 2009, Phylogenetic relationships among families of Gadiformes (Teleostei, Paracanthopterygii) based on nuclear and mitochondrial data: Molecular Phylogenetics and Evolution, v. 52, p. 688-704

Rohlf, F.J., 2005, TpsDig, digitize landmarks and outlines. Version 2.05: Department of Ecology and Evolution, State University of New York, Stony Brook, http://life.bio.sunysb.edu/morph/.

Rosen, D.E., and Patterson, C., 1969, The structure and relationships of the paracanthopterygian fishes: Bulletin of the American Museum of Natural History, v. 141, p. 357-474.

Schwarzhans, W., 1980, Die tertiäre Teleosteer-Fauna Neuseelands, rekonstruiert anhand von Otolithen: Berliner Geowissenschaftliche Abhandlungen, Reihe A, Geologie und Paläontologie, v. 26, p. 1-211.
Schwarzhans, W., 1981, Paläobiogeographische Analyse der tertiären Fischfauna von Neuseeland und Süd-Australien: Geologische Rundschau, v. 70, p. 596-610.

Schwarzhans, W., 1985, Tertiäre Otolithen aus South Australia und Victoria (Australien): Palaeo Ichthyologica, v. 3, p. 1-60.

Schwarzhans, W., 2003, Fish otoliths from the Paleocene of Denmark: Geological Survey of Denmark and Greenland Bulletin, v. 2, p. 1-94.

Schwarzhans, W., 2004, Fish otoliths from the Paleocene (Selandian) of West Greenland: Meddelelser om Grønland, Geoscience, v. 42, p. 1-32.

Schwarzhans, W., 2012, Fish otoliths from the Paleocene of Bavaria (Kressenberg) and Austria (Kroisbach and Oiching-Graben): Palaeo Ichthyologica, v. 12 , p. $1-88$.

Schwarzhans, W., and Bratishko, A., 2011, The otoliths from the middle Paleocene of Luzanivka (Cherkasy district, Ukraine): Neues Jahrbuch fur Geologie und Paläontologie, Abhandlungen, v. 261, p. 83-110.

Schwarzhans, W., Carnevale, G., Bratishko, A., Japundžić, S., and Bradić, K., 2017, Otoliths in situ from Sarmatian (Middle Miocene) fishes of the Paratethys. Part II: Gadidae and Lotidae: Swiss Journal of Palaeontology, v. 136, p. $19-43$.

Scotese, C.R., 2002, Paleomap. Updated at http://www.scotese.com (accessed October 2018).

Shatskii, S.B., 1978, Osnovnye voprosy stratigrafii paleogeografii paleogena Zapadnoy Sibiri, in Shatsky, S.B., ed., Paleogen i Neogen Sibiri (Palaeontologia i Stratigrafia): Novosibirsk, Nauka, p. 3-21 [in Russian].

Stefanovsky, V.V., Zinoviev, E.V., Trofimova, S.S., and Strukova, T.V., 2002, Nikitino is a parastratotype of an alluvial Rezhevsky complex in the Middle Trans-Urals: Ural Geological Journal, v. 1, p. 7-19.

Svetovidov, A.N., 1948, Treskoobraznye [Gadiformes]: Fauna SSSR, Zoologicheskii Institut Akademii Nauk SSSR 34, v. 9, p. 1-222 [in Russian].

Tercerie, S., Bearez, P., Pruvost, P., Bailly, N., and Vignes-Lebbe, R., 2016, Osteobase: World Wide Web electronic publication, http://osteobase mnhn.fr (accessed October 2018).

Trubin, Y.S., 2018, Family Naticidae of the Tavda formation (Eocene, Western Siberia): Ruthenica, v. 28, p. 11-17.

Unified Regional Stratigraphic Schemes for Neogene and Paleogene Deposits of the West Siberian Plain. Explanatory Notes, 2001: Novosibirsk, Siberian Nauchno-Issled: Institute Geologii i Geofiziki Mineral'nogo Syr'ya [in Russian].

Vasilyeva, O.N., 2015, About the age of the Tavda Formation in the Turgai Depression: Yearbook 2014, Institute of Geology and Geochemistry of the Ural Branch of the Russian Academy of Sciences, v. 162, p. 8-20 [in Russian].

Vasilyeva, O.N, Malyshkina, T.P., and Amon, E.O., 2006, Correlation of biozonal scales for dinocysts, foraminifera and ichthyofauna for the Trans-Urals and North Turgai Paleogene: Toporkovskie Readings, v. 7, p. 380-389 [in Russian].

Yasamanov, N.A., 1976, Mezozojskie i Kajnozojskie Klimaty i Landshafty Zapadnoj i Srednej Sibiri: Moskva, Nedra, 141 p [in Russian].

Accepted: 21 February 2019 